A10,12) $3: 29$

PORTO RICO AGRICULTURAL EXPERIMENT STATION,

MAYAGUEZ, P. R.

Under the supervision of the States Relations Service, United States Department of Agriculture.

\title{
BULLETIN No. 29.
}

\section{DAIRYING IN PORTO RICO.}

BY

D. W. MAY, Agronomist in Charge.
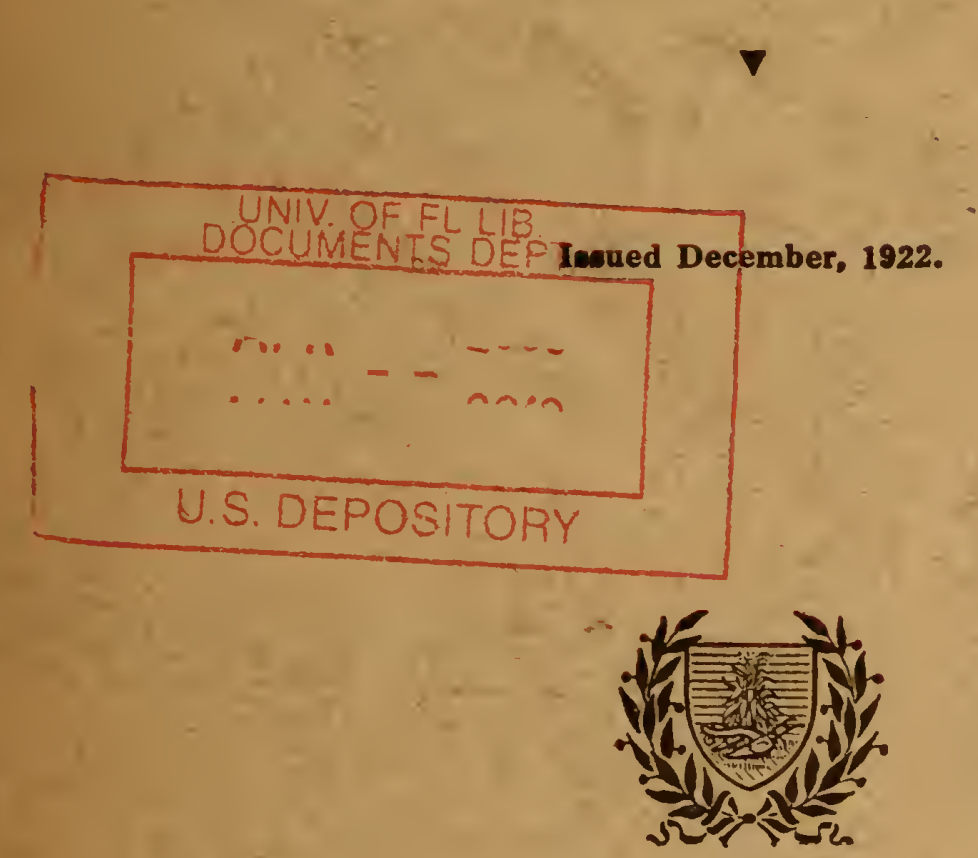

WASHINGTON: GOVERNMENT PRINTING OFFICE 1922. 



\title{
PORTO RICO AGRICULTURAL EXPERIMENT STATION,
} MAYAGUEZ, P. R.

Under the supervision of the States Relations Service, United States Department of Agriculture.

\section{BULLETIN No. 29.}

\section{DAIRYING IN PORTO RICO.}

\author{
BY \\ D. W. MAY, \\ Agronomist in Charge. \\ Issued December, 1922.
}

WASHINGTON:

GOVERNMENT PRINTING OFFICE.

1922. 


\section{PORTO RICO AGRICULTURAL EXPERIMENT STATION, MAYAGUEZ.}

[Under the supervision of the States Relations Service, Uniter States Department of Agriculture.]

A. C. True, Director.

E. W. Allen, Chief, Office of Experiment Stations.

Walter H. Evans, Chief, Division of Insular Stations, Office of Experiment Stations.

\section{STATION STAFF.}

D. W. MAY, Agronomist in Charge.

T. B. MCCrelland, Horticulturist.

IV. V. Tower, Entomologist.

L. G. WILLIS, Chemist.

'T. BREGGer, Plant Breeder.

H. C. Henricksen, Specialist in Farm Management.

J. O. Carrero, Assistant Chemist.

W. P. SNyder, Assistant in Plant Breeding.

J. A. SAldA $\tilde{N}$, Assistant IIorticulturist.

C. Alearar, Jr., Clerk. 


\section{DAIRYING IN PORTO RICO.}

\section{CONTENTS.}

\begin{tabular}{|c|c|c|c|}
\hline Introduction & $\begin{array}{r}\text { Page. } \\
3\end{array}$ & Arailable cattle feeds & $\begin{array}{r}\text { Page. } \\
10\end{array}$ \\
\hline Need of dairying in Porto Rico & 4 & Feeding --_--_-- & 11 \\
\hline Some breeds in Porto Rico & 5 & Silage L-_--_--_ & 12 \\
\hline Selecting the breed._......-_-_- & 7 & Soiling & 13 \\
\hline Improring the breed........ & 8 & Cattle barns and milk sheds & 13 \\
\hline The cattle tick & 8 & Milking & 14 \\
\hline Tuberculosis & 9 & Dairy yields in Porto Rico & 15 \\
\hline The liver fluke._. & 9 & Summary & is \\
\hline
\end{tabular}

\section{INTRODUCTION.}

The cattle generally found in Porto Rico are doubtless descendants of some that mere introduced from Spain at an early date following the discovery of the Western Hemisphere. Probably fer other introductions were made until about the close of the last century, when improred cattle were brought in and merged with the native stock. Of these crosses there is, homerer, little eridence and no record. The introduction of some Zebu blood about 60 years ago had excellent results, which are still visible in the large working stock. With the exception of this strain, the cattle show no evidence of improved blood.

During the 400 years the island was under the Spanish régime, spparently no efforts were made to improre the cattle for any specific purposes. The males rere used principally for draft animals (Pl. I, Fig. 1), and the females were kept for breeding. Dairying was only incidental, the milk being a by-product. Notwithstanding the general lack of care and neglect of selection of breeding animals, the native cattle are of splendid physique and strong frame, features which are due to the luxuriant and nutritious pastures and the equable climate. In milking qualities, however, they fall far below their worth for beef production and as work animals.

(Pl. I, Fig. 2.) The flow of milk is small and the fat content is often variable.

Improrement is being brought about by the introduction of new blood, care in selection, and rational methods in the feeding, care, and treatment of the animals.

The cattle industry in Porto Rico is closely interworen with the sugar industry; one adrancing as the other declines. Formerly, 
large numbers of cattle were exported to Cuba for work in the cane fields. Within recent years, however, the extension of sugar-cane plantings has taken many cattle for working purposes. Cattle are used in plowing the land, cultivating and hauling cane to the mill, and in the old days they were employed for grinding. The cane fields are rotated by letting them go back to grass, and the only use that can be made of the grass is in the feeding of cattle.

The Porto Rican farmer finds it easy to shift into one of these industries when the other is on the wane. As soon as the margin in sugar growing falls, the fields are allowed to grow up to pasture with the resultant increase in the number of live stock raised. The surplus stock is then shipped to Cuba and other islands of the West Indies, where the Porto Rican ox is in demand as a work animal and preferred on account of his strength and gentleness. When sugar rises in price, the fields are plowed and the number of cattle on the cane plantation is greatly reduced. Since the American occupation, sugar has been the leading industry, and for this reason the cattle industry has not kept pace with the other lines of agriculture. No cattle were exported during the time sugar was bringing high prices. The production of beef and milk is not large enough to supply local needs. The ralue of meat products imported into Porto Rico during the year 1920 was $\$ 6,887,519$, and of condensed and evaporated milk, $\$ 643,047$.

\section{NEED OF DAIRYING IN PORTO RICO.}

No system of agriculture is complete or well grounded unless it includes within its scope the production of cattle. Cattle are needed, if for no other purpose, to consume the waste products of the farm and to help conserve the fertility of the soil. Probably no other branch of farming would pay as well at this time in Porto Rico as dairying. With the steadily increasing population there has been a growing demand for milk. Fresh milk, perhaps the most perfect of all single foods, is scarce in all sections of the island, and retails at the excessive price of from 15 to 25 cents per quart or liter (approximately 2 pounds). The supply is far below the demand. Canned milk, cream, and butter are imported from the States, but canned dairy products, no matter how good they may be, are not equal to the fresh articles, and in many cases they can not be substituted for them. Dairies have sprung up in all parts of the island. In some instances the mills is produced by native cattle alone, and in others by native cattle that have been crossbred with improved sires. In a few instances purebred herds have been introduced with varying success. All the recently imported cattle hare come from the States. 
Recognized breeds of domestic cattle may be placed in one of two general classes: Animals that are bred primarily for beef production and those that are bred for their milking qualities. Determination of which class will prove the most profitable in a given country depends upon the demand for products, availability of labor, and the cost of feed. In case of cattle intended for slaughter the prime consideration is for the amount of beef that they will dress. For this purpose there is sought a type of animal that will mature quickly and lay on the greatest amount of flesh with the least amount of feed. The beef type is block-shaped. Dairy cattle are sought for milk production. The dairy type of animal is redge-shaped; that is, having large hind quarters and thin fore quarters.

One of Porto Rico's greatest needs at the present time is the development of dairying to supply milk for local purposes and for making butter and cheese for home consumption. This need is emphasized by the fact that the profits from raising cattle for dairy purposes are larger than are obtained from any other branch of animal production.

\section{SOME CATTLE BREEDS IN PORTO RICO.}

The cattle introduced into Porto Rico are, almost without exception, dairy breeds, Holstein-Friesians being in the lead, with Guernseys, Jerseys, and Ayrshires following.

\section{JERSEYS.}

Thirteen miles off the coast of France, and within 50 miles of the southwestern extremity of Great Britain, lie the Channel Islands, the largest of which is known as Jersey. It is 6 by 11 miles in extent. This island is the home of the Jersey breed of cattle, which is one of the most widely distributed of the dairy breeds. The Jerseys have been purely bred since $17 \% 9$, when a law was passed and since strictly enforced prohibiting the introduction of live cattle into the island. Through a succession of years the cattle have been judiciously selected until there has dereloped a race of inherent constitutional vigor and high productive capacity.

Conditions in Jersey are similar to those obtaining in Porto Rico, food crops constituting the principal production, and the cattle being used largely to consume the fodder and surplus waste products. The animals are tethered in the fields, where they are advanced daily so that they may gradually graze the whole field. Cows are household pets in Jersey and are very carefully tended.

Jersey cattle are the smallest in average size of the well-known dairy breeds. The mature cows weigh from 700 to 1,000 pounds each. The breed is variable in color, ranging from fawn to gray and mouse, though generally solid colored. White patches occa- 
sionally mark the body. Among some breeders black muzzles, tongue, and switch are preferred. The arerage of the 12,258 cows in the United States that had completed yearly records for the register of merit up to October 20, 1919, is 7,931 pounds of milk testing 5.35 per cent. The milk contains a high percentage of total solids, especially butterfat, 4.5 to 6 per cent of fat being not unusual. The butter records are correspondingly large, from 350 to 400 pounds of butter being annually produced by each milking animal. Buyers from all parts of the world go to the island of Jersey to purchase these cattle and willingly pay high prices for the best animals.

\section{GUERNSEYS.}

Guernsey, which is 4 by 9 miles in extent and the second largest of the Channel Islands, is the home of the Guernsey cattle, the origin and history of which are the same as those of the Jersey breed. The Guernseys have been kept a distinct breed for many years by the exclusion from the island of all other cattle.

The Guernsey is larger than the Jersey and is stronger boned. The average weight of mature cows is about 1,000 pounds. The Guernsey is light in color, white and yellow predominating. (Pl. II. Fig. 1.) Darker shades are occasionally found on some of the cows and commonly on the bulls. This breed is somewhat like the Porto Rican cattle in conformation, size, and color. The Jerseys and the Guernseys have short hair and have been developed in a mild climate. Both do well in Porto Rico except for attacks of tick fever. The Guernsey is a high producer of milk, which is nearly as rich in butterfat as is that yielded by the Jersey. The arerage production of 8,896 cows in the United States that had completed a year's record for advanced register to January 15, 1920, is 9,030.5 pounds of milk testing 5.015 per cent.

\section{AYRSHIRES.}

The Ayrshire breed originated in the county of Ayr, in southwestern Scotland. It is only within the last hundred years, however, that these cattle have become so distinct in their characteristics as to be considered a breed. Doubtless the breed as it is to-day is the result of infusions of blood from the cattle of England, Holland, and the Channel Islands. In color the cattle vary from medium red to dark mahogany-brown and white, either of which may predominate. They are not as gentle as the Jersey cattle. They are somewhat less readily acclimated to tropical conditions because they are a distinctly northern breed.

The Ayrshire cow varies in weight from 900 to 1,300 pounds, the average weight being 1,100 pounds at maturity. Ayrshires are good milkers, and the average of 3,319 cows and heifers in the 
United States that had completed yearly records for advanced registry to June $\widetilde{5}, 1919$, is 9,621 pounds of milk testing 3.96 per cent. The fat content of the milk ranges from 3.5 to 4 per cent. The fat is in uniformly small globules, and does not separate freely from the milk. For this reason the milk will not churn in shipment. While not a first-class butter cow, the Ayrshire is considered a fair yielder of milk which is safely above legal standards and admirably suited for city and town supply.

\section{HOLSTEINS.}

The Holstein, or more properly the Holstein-Friesian, has been bred for centuries in the northern part of Holland, where the climate is cool. There the cattle are most tenderly sheltered, fed, and groomed. In the spring they are placed in the fields as soon as the grass has grown sufficiently for grazing, and in the summer they are protected from the sun by canvas covers. On account of the very farorable climatic conditions and careful treatment under which they hare been reared in Holland, the Holsteins are not likely to adapt themselves to the tropical conditions of Porto Rico as readily as are some of the other breeds. They should, therefore, be imported with great care and not be turned out to rustle on scanty pasturage. They should be sheltered from the sun and fed a plentiful supply of succulent grasses.

The Holstein is the largest of the dairy breeds, and has a large, strong frame and an abundance of flesh. In color the cattle are black and white. At maturity the cows weigh about 1,400 pounds and yield milk in proportion to their size. The average of 4,974 cows in the United States that had completed a yearly record for the adranced register to April 30,1919, is 14,783 pounds milk testing 3.42 per cent. The milk has little color and its fat content is low, from 3 to 4 per cent. There are some Holstein families, however, which vield milk of more than average richness.

\section{SELECTING THE BREED.}

Dairy breeds are all alike in so far as general tendencies are concerned, but they differ and some excel other's in certain special features. The stock farmer should, therefore, take particular pains to select a breed of cattle that will yield him the greatest profit and be well suited to local conditions. Personal preference, however, should also be considered, because a breeder can do the best work with the breed of cattle that he fancies most.

Cows giving milk haring a deep-yellow color, thought to be an indication of richness, are sometimes preferred to others whose milk is white or opalescent, but the yellowish tinge may be derived from 
certain feeds and may therefore have nothing to do with richness. Again, large dairy cattle are often preferred to small in the belief that they have possibilities of greater production on account of the larger amount of feed they consume. Too much stress should not be placed upon size.

Only those factors which make for the success of the dairy cattle business should be given consideration in the selection of cattle.

\section{IMPROVING THE BREED.}

The fundamental principles involved in building up a dairy herd in Porto Rico are essentially the same as those obtaining in the Temperate Zone. Porto Rico has a splendid foundation stock adapted to local conditions upon which to build up a superior dairy industry. Cattle which do not naturally adapt themselves to climatic conditions can not be expected to attain their maximum of efficiency. By the importation of some of the best breeds of cattle, or by rigorous selection and careful crossing of the native cattle, the Porto Rican farmer should be able to develop after some years a race of cattle that will rank with or excel the improved breeds of the world.

Effort to improve the breed should be confined to one particular type, rather than given to an indiscriminate mixing or crossing of two or more breeds. Like tends to produce like, and for this reason the stockman should endeavor to build up his stock by the introduction of improved animals. Probably the quickest way to build up a herd is (1) by the purchase of high-grade animals having the ability to transmit their characteristics to their offspring; (2) by systematic breeding and judicious feeding; (3) by eliminating all low-yielding females; (4) by improving the general average of the females by the purchase of males which will keep the strain pure and tend to increase the milk yield; and (5) by establishing improved breeds. A number of the Porto Rican crossbred animals show improved conformation and probably earlier maturity by reason of the cross (Pl. II, Fig. 2).

On account of the prevalence of the cattle tick, the stock raiser will do well to confine his purchase to the best native cows, regardless of whether they are native or graded stock, and import the very best bull that he can afford. The stockman is, however, justified in importing purebred cattle if he is prepared to meet the losses that occasionally occur in acclimating the stock, has a dipping tank in which to dip the cattle periodically, and provides a shelter from the sun and a plentiful supply of succulent grasses for the animals.

THE CATTLE TICK (Margaropus annulatus).

The cattle tick (Margaropus annulatus) is very abundant in Porto Rico and carries from one animal to another the discase commonly 
known as tick fever. Young imported cattle stricken with the ferer come through with small losses if they are carefully looked after for a few months and fed largely on green grasses. The older imported cattle, however, are more severely attacked, and there is a greater percentage of loss among them. Introduced cattle become tick infested soon after their arrival unless they are given very special attention and care. Unfortunately, the average Porto Rican farmer is not prepared to give his cattle the best treatment, and great losses are common among the imported cattle. In the few instances where the cattle do not succumb to tick fever, their vitality is lowered to such an extent that they seldom fully recover.

The tick is the great enemy of the cattle industry. It plays havoc with the health of the cattle, drawing blood that would otherwise produce milk or flesh and impeding circulation. The animals lose in fiesh and energy and soon become a source of expense to the owner, who is obliged to feed an unusually heavy ration to maintain life. Cattle that are dipped at intervals show a decided gain in weight over untreated animals. The work of dipping cattle to free them from the tick is not only very effective, but it is also easy and practical. There are now about 100 dipping tanks on the island, and the necessity of exterminating the tick is beginning to be realized. Stringent measures should be adopted toward this end. An energetic campaign, conducted by the island government, could be carried on (1) by detailing men to all sections of the island to dip at regular intervals every animal within a given area until it is cleaned; and (2) by quarantining each cleaned section until the whole island has been covered. When the tick is unable to secure bovine blood for one generation it can not reproduce and dies. An area in which this occurs then becomes free from infestation until another tick is brought in. Once the tick is eradicated in Porto Rico, quarantine regulations can be adopted at little cost to keep it out.

\section{TUBERCULOSIS.}

With the exception of tick ferer there is no especially serious disease of cattle in Porto Rico. No general statistics are available as to the presence of bovine tuberculosis, but it is thought that the island is comparatively free from this disease. Two herds of native cattlo belonging to the agricultural college and to the experiment station were tested, but neither herd contained reactors.

\section{THE LIVER FLUKE (Fasciola hepatica).}

Liver rot, a disease caused by a small parasite known as the liver fluke (Fasciola hepatica), commonly affects the cattle in some sections of Porto Rico. At the slaughterhouse these parasites are discernible in great numbers in the livers of the dead animals. The 
liver fluke breeds in stagnant water and is taken into the body from drinking such water. The growth of young animals is materially checked by the parasite, which darkens and congests the hepatic lymph glands, weakens the heart action and the jugular pulse by disturbing the hepatic circulation, and enlarges the liver. Loss due to the parasite may be prevented to considerable extent by avoidance or drainage of marshy places and stagnant water. and by providing the cattle with fresh water protected from contamination.

\section{AVAILABLE CATTLE FEEDS.}

Cattle readily adapt themselves to countries having a plentiful supply of nutritious grasses, and they make thriftier growth in such places than they do where the pasturage is scant. An increase in the production of grasses suitable for grazing purposes is naturally followed by a development in animal production, and the crops are converted into beef, milk, and butter with the least expenditure of money for labor. Likewise, a decrease in grass production is followed by a decline in the stock-breeding industry. To produce hardy cattle, therefore, the stockman must grow an abundance of grasses that have a high feeding value so that the animals will either put on flesh or yield large quantities of milk.

Porto Rico offers great possibilities for the production of nutritious grasses. Many of her idle lands could be turned into profitable pasture lands, and the lands now in pasture could be made to produce a larger quantity of rich grasses. The high lands of the island produce many native grasses that are inclined to be wiry and low in yield, some of them bearing only little leaf. The station recently introduced for use on these lands a variety of grass (Polytrias promorsa) which gives much promise as a pasture grass. Para grass (Panicum barbinode), or malojillo, is the leading grass on the lowlands. It is a vigorous grower and is much relished by cattle. Guinea grass ( $P$. maximum) flourishes in the limestone sections of the island and produces the highest type of feed. Breeding stock is raised to the best advantage in regions where this grass is grown.

Of the several grasses introduced by the station, elephant or Napier grass (Pennisetum purpureum) produces the largest quantity of forage (Pl. III, Fig. 1), yielding in one trial 19 tons per acre on high land within seven months after.planting. Some of the earliest plantings at the station have been ratooned for six years. Elephant grass thrives on a variety of soils and is greatly relished by cattle, the entire stalk being eaten, provided it is cut before becoming woody. Elephant grass has given the greatest impetus to dairying in Porto Rico of any crop that has been introduced. It has high value as a stock feed. Much of the unproductive land should be planted in this excellent grass. 


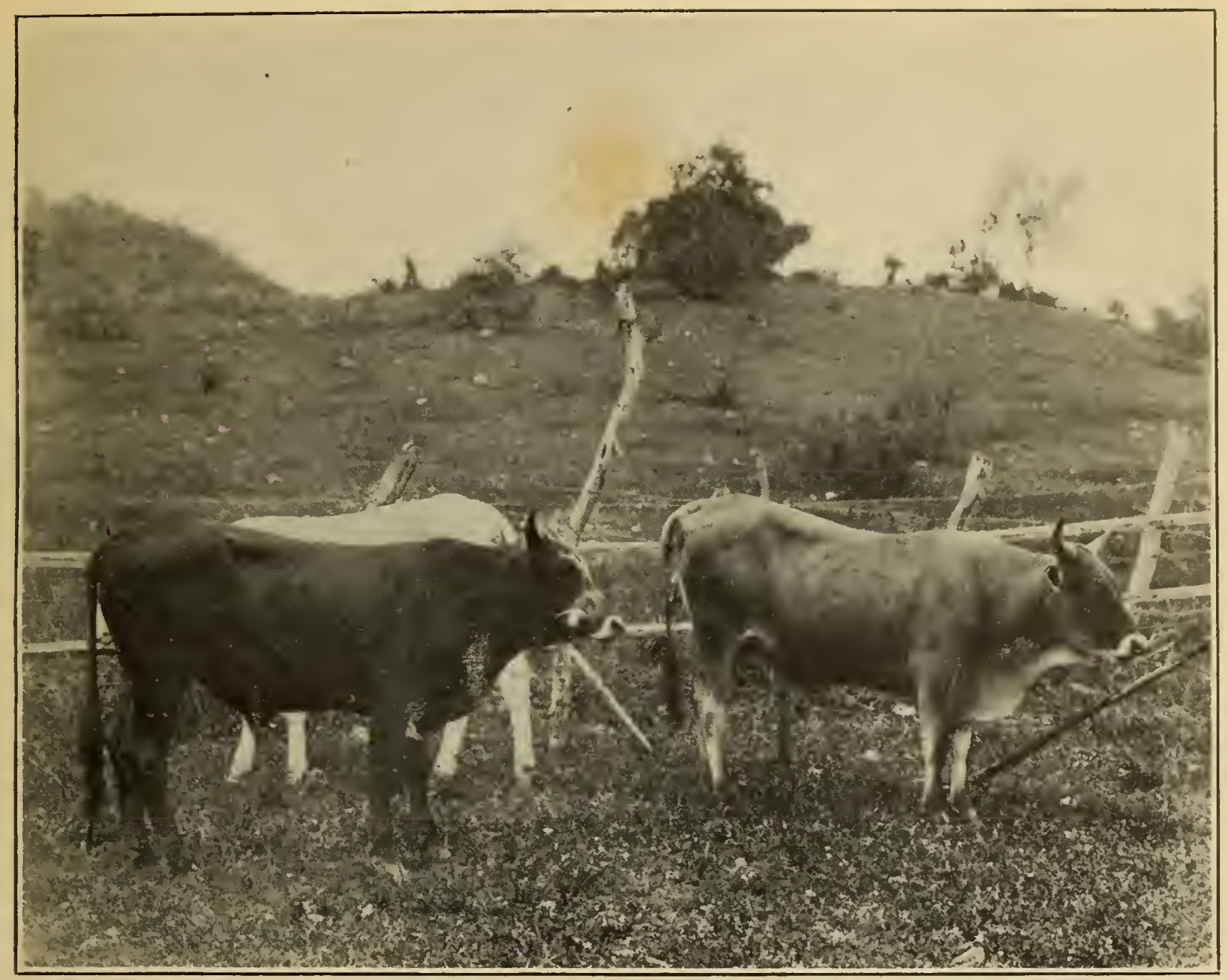

Fig. I.-Typical Porto Rican Cattle.

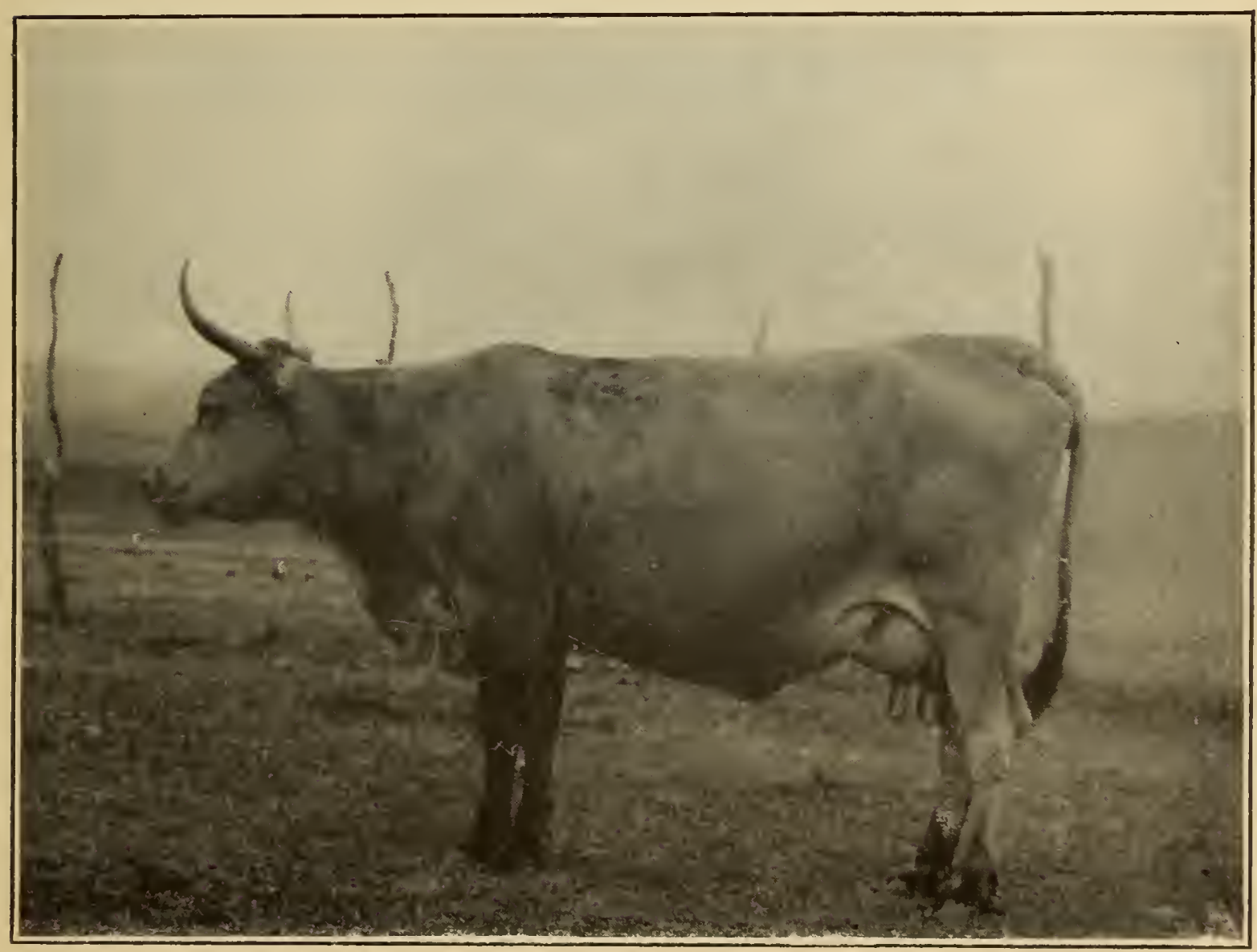

Fig. 2.- Highest Yielding Native Cow in Test. 


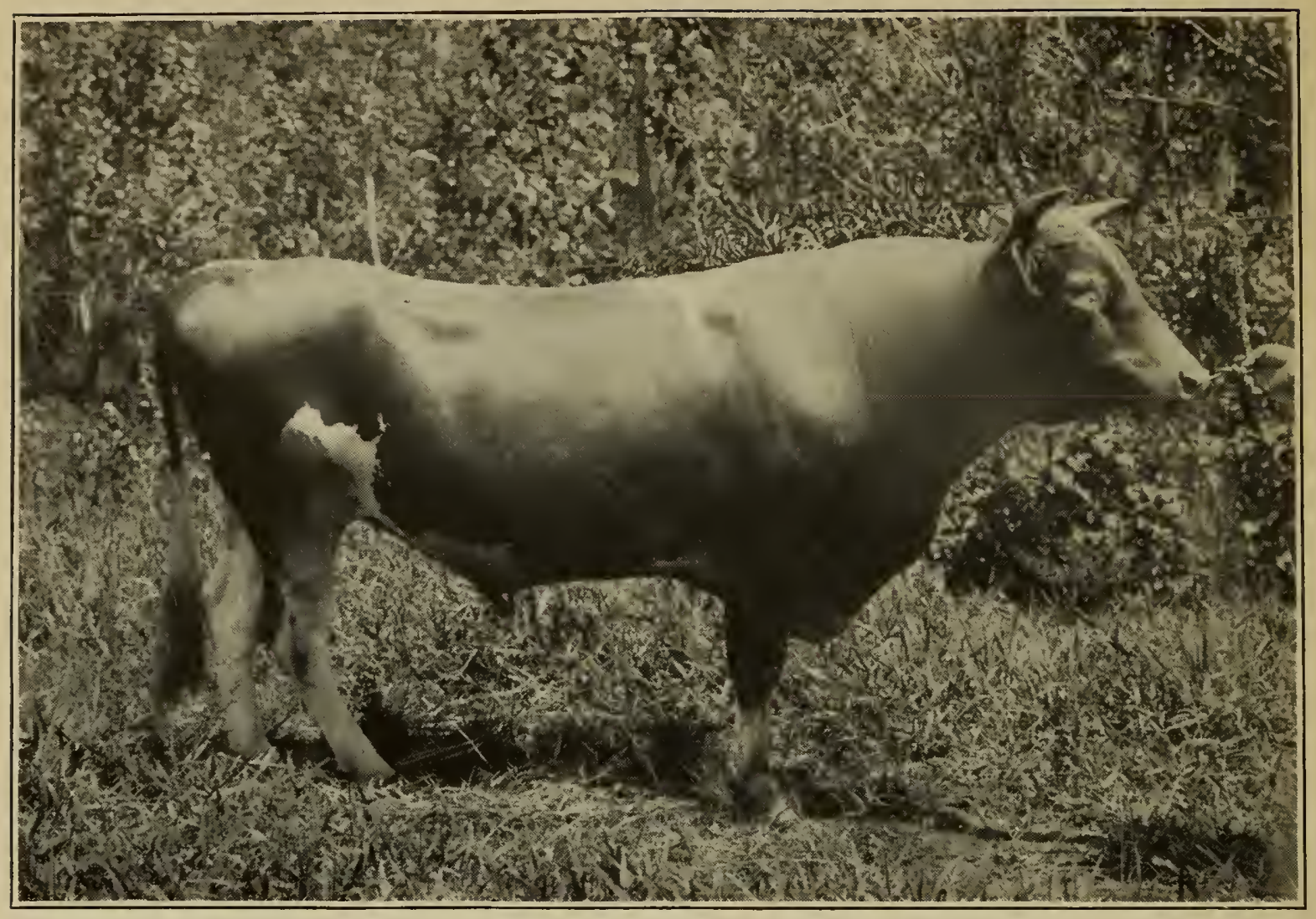

Fig. I.-Station Guernsey Bull.

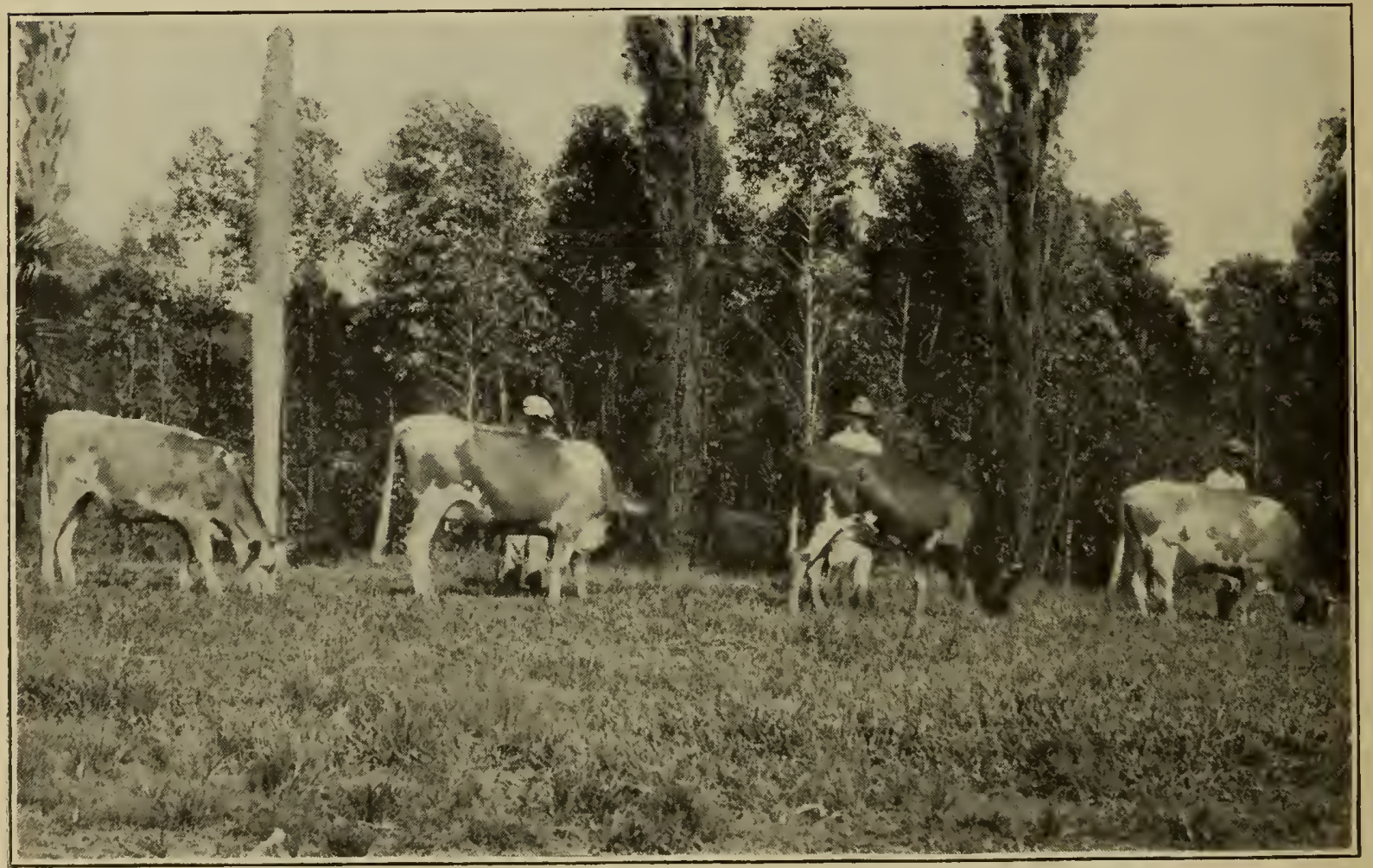

Fig. 2.-Crossbred GUeRnSEy CoWs AND HeIfERS. 


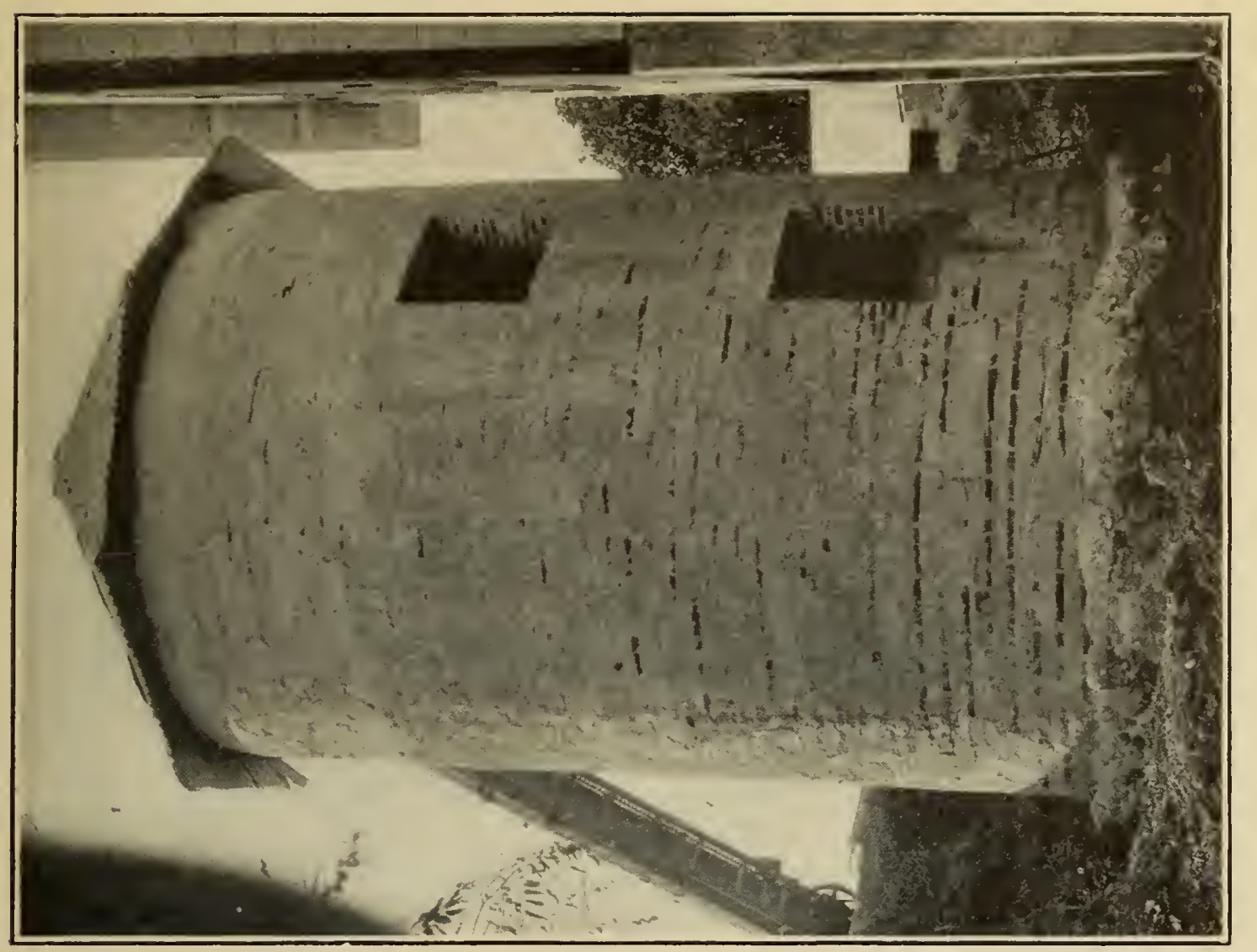

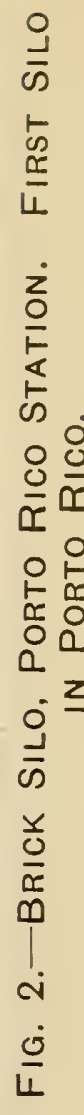

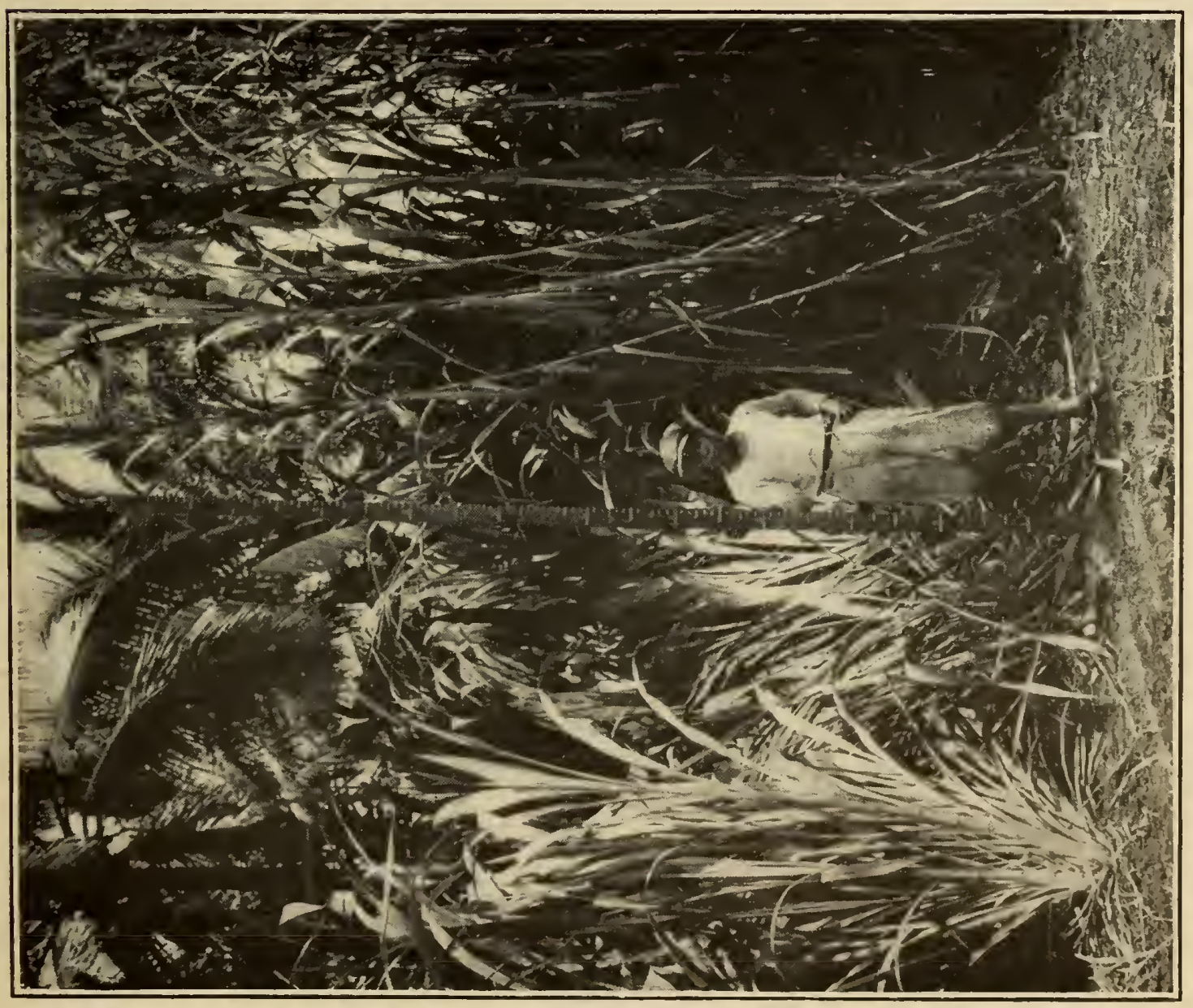




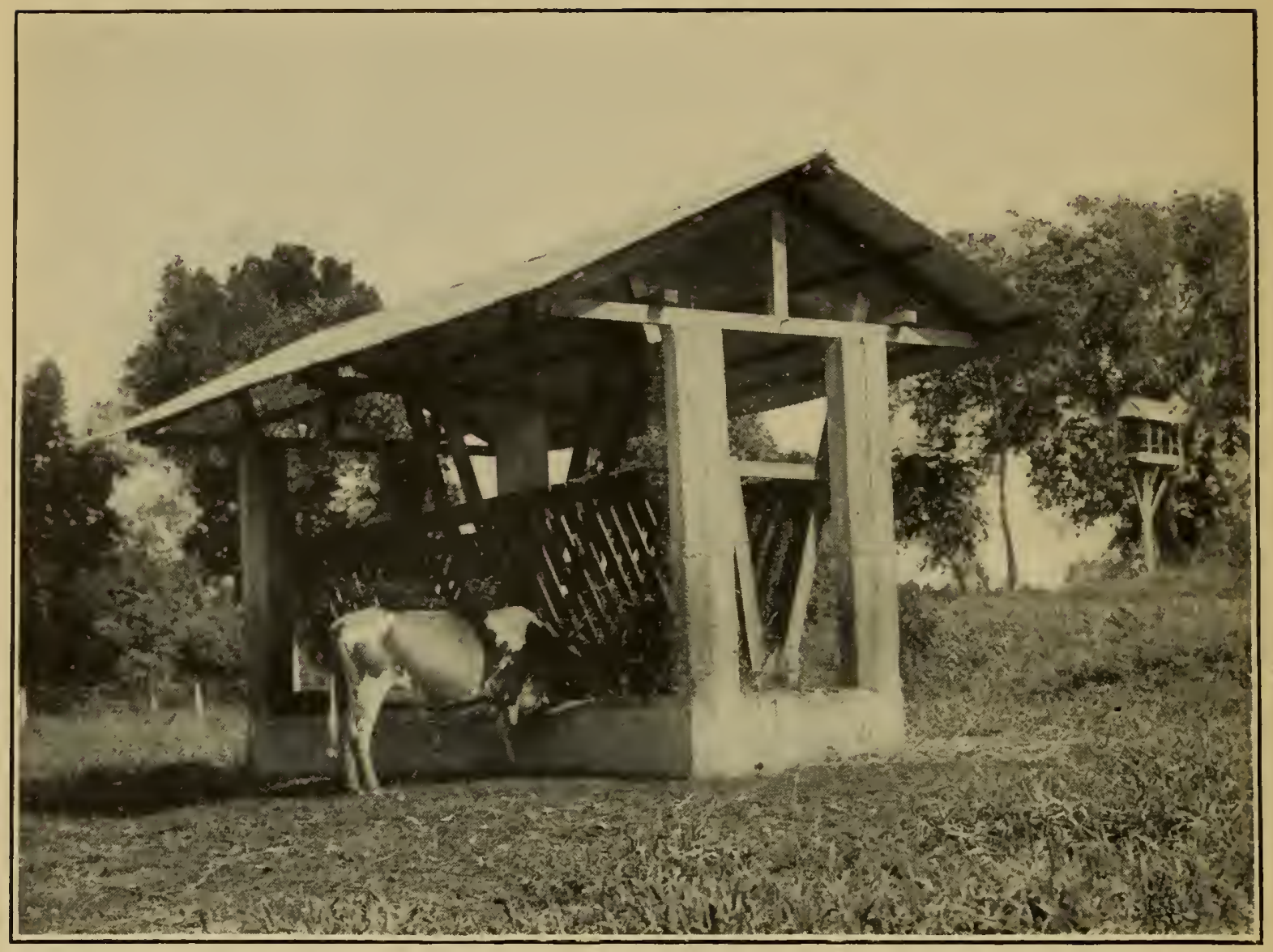

Fig. I.--FeEding Rack for Fresh Cut Grass.

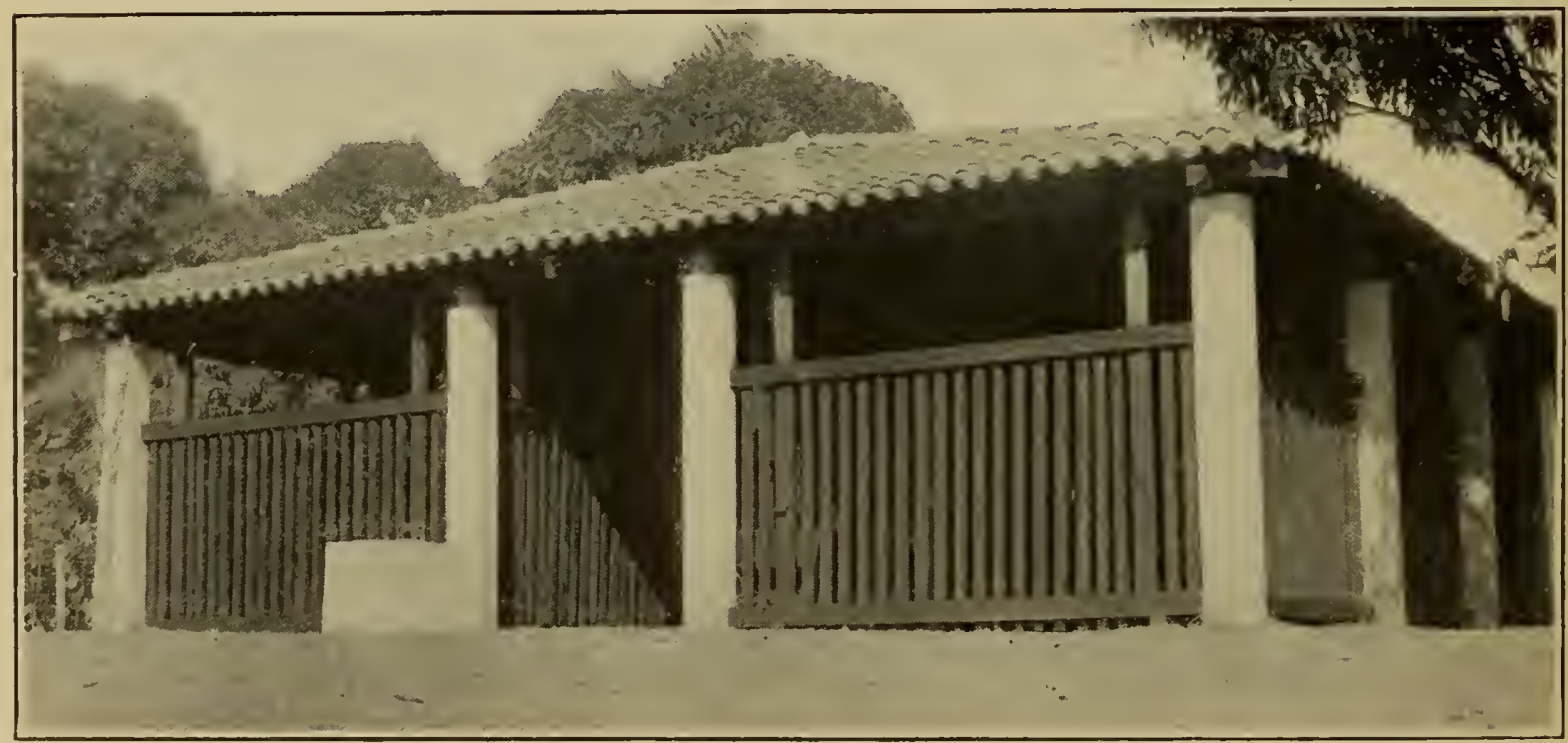

FIG. 2.-BULL BARN, EXPERIMENT STATION. 
All of the sorghums make excellent growth in Porto Rico. Plantings of the leading varieties are being extended to all parts of the island.

The forage sugar canes also merit consideration as feed for live stock. The Japanese canes make thrifty growth on very poor lands, and are not as susceptible to the mottling disease as are some of the better-yielding varieties. During the rainy season some of the Japanese canes tested at the station have yielded 33 tons of fodder cane within seven months after planting. Cane tops and molasses, by-products of the sugar industry, are largely entering into the feeding of cattle.

Many of the leguminous plants furnish a large amount of feed for cattle. Of the varieties introduced for this purpose by the station, none has done so well as has the velvet bean. This crop can be planted when the last crop of cane has been harrested, and it will improve the soil for replanting to cane. It could also be planted in many waste places and along fence rows. Crotalaria juncea, or sunn hemp, makes the greatest growth in the shortest time of any legume tried at the station. It is grazed to some extent by cattle and is also fed in the corral. Cowpeas, especially the running varieties, can be profitably grown for forage purposes. They make rapid growth and the crop when used as forage tends to decidedly improve the quality of the milk. The residue of some of the beans and pigeon peas, locally called "gandules," can also be utilized as cattle feed. Corn, the king of the grasses, grows successfully in all sections of Porto Rico at some time of the vear, and the by-products can be used to feed cattle.

\section{FEEDING.}

Methods of feeding should be arranged so that a given acreage will carry the maximum number of cattle. Feeding should be done as economically and conveniently as possible. Some farmers like to feed their cattle in the stall, and others prefer feeding from a rack. The latter is undoubtedly the more economical of the two methods because all grass that is pulled from the rack falls into the cement trough below and is picked up by the animals, and the residue, which collects around the base of the rack with the manure, can be readily gathered up and transported to the field. (Pl. IV, Fig. 1.) Results obtained in a test conducted at the station to determine the more economical of the two methods, showed that the consumption of elephant grass was 92.5 per cent when it was chopped and fed in the stall, and 91.2 per cent when it was fed whole from the rack. The small gain in consumption when the grass was chopped and fed in the stall was not sufficient to pay for the extra labor involved. Taking this into account, there was a slight but economically important difference in favor of the rack method. 
Notwithstanding the prevailing high prices paid for concentrated feeds, Porto Rican dairymen are importing them in larger quantities every year. As long as milk continues to bring high prices this importation can be profitably made, but bran, shorts, cottonseed meal, corn meal, and some of the proprietary feeds should never be used in any large amount. Grasses make the most economical feed and should be fed in abundance, as witness the native stock, which have never been fed concentrates and which thrive well on grass even when it is poor in quality and insufficient in quantity. The following table gives the feeding value of some of the grasses which grow in Porto Rico:

Composition of some grasses growing in Porto Rico.

[On basis of fresh green material.]

\begin{tabular}{|c|c|c|c|c|c|c|c|c|}
\hline Kind of grass. & Moisture. & Ash. & Frotein. & $\begin{array}{l}\text { Crude } \\
\text { fiber. }\end{array}$ & Fat. & Sucrose. & $\begin{array}{l}\text { Rerluc- } \\
\text { ing sugar. }\end{array}$ & $\begin{array}{c}\text { Carbo- } \\
\text { hydrates } \\
\text { not sugar. }\end{array}$ \\
\hline $\begin{array}{l}\text { Guatemala.. } \\
\text { Elephant... } \\
\text { Guinea..... } \\
\text { Malojillo... }\end{array}$ & $\begin{array}{r}\text { Per cont. } \\
81.89 \\
86.31 \\
69.57 \\
76.04\end{array}$ & $\begin{array}{r}\text { Per cent. } \\
1.68 \\
1.34 \\
3.14 \\
2.04\end{array}$ & $\begin{array}{r}\text { Per cent. } \\
0.95 \\
.69 \\
1.23 \\
1.24\end{array}$ & $\begin{array}{r}\text { Per cert. } \\
6.35 \\
4.56 \\
11.54 \\
8.06\end{array}$ & $\begin{array}{r}\text { Per cent. } \\
0.19 \\
.17 \\
.36 \\
.44\end{array}$ & $\begin{array}{r}\text { Per cent. } \\
0.06 \\
.17 \\
.30 \\
.43\end{array}$ & $\begin{array}{r}\text { Pcr cent. } \\
0.39 \\
.77 \\
.53 \\
.63\end{array}$ & $\begin{array}{r}\text { Per cent. } \\
3.59 \\
2.74 \\
6.21 \\
5.03\end{array}$ \\
\hline
\end{tabular}

Salt should be kept before the animals at all times. The milk yield decreases considerably when it is withheld. Generous quantities of drinking water, as good as that used for household purposes, should be supplied the animals several times daily, but especially in the morning before rumination (chewing the cud) takes place. The average cow needs from 50 to 100 pounds of water a day, depending upon the ration.

Cattle should be fed" at the same hours each day, because regularity and uniformity in feeding have much to do with the profits resulting from dairy farming operations, and they are potential factors in influencing the milk yield. The cattle should always be kept free from excitement and fright. As soon as the average Porto Rican stockman learns to appreciate the relative values of the different stock feeds and how to select wholesome feeding stuffs he will be able to grow his stock more economically than he now does.

\section{SILAGE.}

Silage is green fodder that has been kept in an air-and-water-tight silo. The station erected the first silo in Porto Rico (Pl. III, Fig. 2), and has successfully ensiled corn, the silage being equal to that produced in the States and greatly relished by cattle. Cane tops did not make a very good product. Fermentation does not take place when the tops are too dry, and it passes from the alcoholic to 
the acetic stage when they contain too much moisture. The resulting silage is consequently sour. It is difficult to determine the proper stage at which cane tops are in condition for silage making. Cane silage has been eaten with relish by the station mules, but the cattle have differed in this respect, and none of them show the liking for it that they do for corn silage. Experiments in ensiling malojillo and guinea grasses were unsuccessful. The material is too light and does not settle or pack sufficiently unless heavily weighted: neither does it ferment well or develop the aroma that is given off by "sweet" silage.

\section{SOILING.}

In the Tropics, where there is a continuous growing season, grass should be cut for feeding purposes while it is in the succulent stage, so that the animals will eat the entire stalk as well as the leaves. This stage can be determined only by experiment. Cattle will eat the larger portion of the grass if it is fed in the stall. When it is plentiful, howerer, the grass may be fed upon the ground; otherwise, the cost of cutting may be more than it is worth.

\section{CATTLE BARNS AND MILK SHEDS.}

The solid structures used in the North are not needed to house cattle in Porto Rico, where the climate is tropical. A stable, suitable for tropical conditions, can be made of wood, but it should be built on a foundation of earth that is well drained. Cement floors are the best, but those of well-tamped clay are usually satisfactory. The roof should slope so that it will shed water readily, and it should be of a material that will break the force of the sun's heat. Handmade clay tiles, which can be obtained at a reasonable price in almost any section of Porto Rico, are excellent for this purpose. They have been made at the station at a cost of $\$ \tau$ per thousand, but they can be had at a much less price where old buildings are being torn down. When clay tiles are used, the roof should be well supported by rather heavy timbers. (Pl. IV, Fig. 2.) A thatched roof is easy and inexpensire to make, and boards, covered with tar paper, are also serviceable for roofing, although they have no lasting qualities. An iron roofing will afford protection from rain, but on account of its heat-transmitting properties it should not be used for stables where cattle are permanently quartered. The stable should be walled on the side from which strong winds blow.

The stalls should be of sufficient number to permit of the animals being changed from one to another, so that the earth in each stall can be thoroughly dried and cleaned at regular intervals.

Milking sheds may also be constructed of rood, but they should have a cement flooring so that they can readily be flushed. After 
being flushed, they should be aired to dry out quickly. The milk room should be frequently whitewashed and kept free from cobwebs and dirt. It should be well lighted and the windows screened to keep out the flies. The utensils used in the milk rooms should be kept scrupulously clean, and if hot water is not available they should be placed in the sun daily for a few hours. All sour milk should be removed from the milk room, which should be used exclusively for cooling and storing, straining, mixing, and aerating milk.

Lime is an excellent disinfectant for spreading over the surface of the earth floorings. Tamped earth, like clay, makes better flooring than do either sand or gravel and it can be kept cleaner. Air and sun, the two great natural disinfectants, should be admitted to the stable and milk room at all times, unless, of course, they interfere with the general comfort of the animals.

The cattle should be kept in the open as much as possible, but within easy access to shade. Animals imported from the North should be kept in a shed for some months at least, being allowed in the open only in the early morning, late afternoon, and at night. When in the pasture they should be protected from ticks.

\section{MILKING.}

Milking should be done in the milking shed where sanitary concitions can be maintained. Before attempting to milk, the milker should carefully wash his hands with soap and water and rinse them in clean water. Cows should be thoroughly cleaned some time before milking, the skin and hair, particularly the udder, being thoroughly groomed and brushed to remove manure and other filth. The cows should not be brushed in the milking shed, or at least not immediately before milking, because the resulting dust will settle in the milk. If the animals are tied in the stall and given 1 pound of concentrated feed at milking time, they will let down the milk readily and without undue excitement.

In all up-to-date dairies the calf is weaned soon after its birth and the cow is trained to deliver the milk without it. The calf can be taught to drink milk from a pail by letting it suck the forefinger immersed in the milk. The finger should be withdrawn gradually so that the calf will draw the milk into its mouth in the natural manner of drinking. Some milkers are more efficient than others in obtaining a large quantity of milk at each milking. The milker should be trained to "strip" the cow, that is, to remove the milk more completely from the udder. Stripping, in addition to considerably reducing likelihood of bacterial infection of the udder, promotes and maintains the milk yield, resulting in a flow of milk 
much richer in fat than that which was first obtained. Careless milking will reduce the quantity and lower the quality of the milk of the best cow.

Milk being a perishable product deteriorates rapidly unless it is carefully protected from contamination from the time it is drawn from the cow to that of its use by the consumer. As soon as it is drawn the milk should be strained through a sterilized cloth to remove hairs, dust, and the like. It should then be placed in a clean pail having a lid that can be fastened down securely. The milk should be kept in a cool place and where it will not develop odors. Proprietary and chemical preservatives are harmful and should never be used. When milk is cooled immediately after being drawn its keeping quality is much improved. In the Tropics cooling is difficult unless ice can be obtained. There are sereral cooling devices to be had, and when the milk is held for a few hours and ice can be obtained at a reasonable cost it will pay to employ them. Milk that is left over at the end of the day should be put through a separator so that the fat can be drawn off for butter-making, and the skimmed milk fed to the calves. By means of a separator the dairyman can handle milk quickly, churning it into butter before it has a chance to spoil. At the station, milk has been made into sweet-cream butter that kept for some time. Practically all the butter used in Porto Rico is imported, and sweet-cream butter should find a ready market in all sections of the island.

Cheese can be made on the farms without expensive equipment. Some cheese is now made in Porto Rico and sells at good prices on the local market. The method of making cheese should be improved, however, to benefit the industry and increase the quality of the product.

At the present time milk is perhaps the most profitable form in which to market dairy products. To avoid loss, however, dairymen should be prepared to convert surplus milk into butter or cheese. Milk is usually sold in Porto Rico as soon as possible after it is drawn.

\section{DAIRY YIELDS IN PORTO RICO.}

The output of milk of the native cow is low. The poor flow of milk is attributed to two facts: (1) Failure to improre the cattle by selection of animals possessing good dairy characteristics; and (2) failure to handle and manage the cattle in a manner conducive to increased dairy production.

The experiment station recently made a study, covering eight months, to determine the approximate milk yield of native cows, together with the cost of the product, and the profits accruing after the cost of handling was deducted. The figures were obtained by 
following a method derised by the Dairy Division, Bureau of Animal Industry, United States Department of Agriculture, ${ }^{1}$ and the data are recorded at the station for those dairymen in Porto Rico who are anxious to learn (1) to determine the actual value of each cow in their herds; (2) to compare the dairy yield of native with that of improved cattle; (3) the present condition of the industry; and (4) methods of improving it. The following table gives the general results obtained, but does not show the cost or profits:

General results of comparative tests made to determine the dairy yield of cous in Porto Rico.

\begin{tabular}{|c|c|c|c|c|c|c|c|c|}
\hline \multirow{2}{*}{$\begin{array}{l}\text { Testing period } \\
\text { (8 months). }\end{array}$} & \multirow{2}{*}{$\begin{array}{l}\text { Number } \\
\text { of cows } \\
\text { tested. }\end{array}$} & \multicolumn{2}{|c|}{$\begin{array}{l}\text { Approximate milk } \\
\text { yield of herd. }\end{array}$} & \multirow{2}{*}{$\begin{array}{c}\text { Butter- } \\
\text { fat yield } \\
\text { of herd } \\
\text { per } \\
\text { month. }\end{array}$} & \multicolumn{3}{|c|}{ Butterfat test per cow. } & \multirow{2}{*}{$\begin{array}{l}\text { Average } \\
\text { daily } \\
\text { milk pro- } \\
\text { duction } \\
\text { per head. }\end{array}$} \\
\hline & & Daily. & Monthly. & & Lowest. & Highest. & A rerage. & \\
\hline 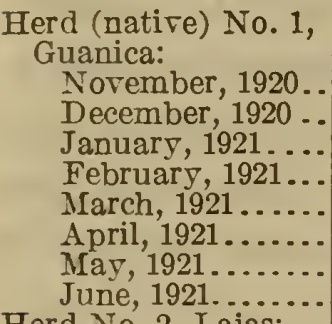 & $\begin{array}{l}66 \\
82 \\
77 \\
71 \\
62 \\
50 \\
54 \\
73\end{array}$ & \begin{tabular}{r|} 
Pounds. \\
327.2 \\
459.7 \\
444.3 \\
505.7 \\
40.7 \\
291.4 \\
254.8 \\
524.5
\end{tabular} & $\begin{array}{r}\text { Pounds. } \\
9,816.0 \\
14,203.3 \\
13,778.5 \\
14,160.6 \\
12,558.1 \\
8,742.0 \\
7,898.8 \\
15,735.0\end{array}$ & $\begin{array}{r}\text { Pounds. } \\
382.32 \\
548.42 \\
520.80 \\
472.98 \\
409.15 \\
329.56 \\
282.14 \\
446.76\end{array}$ & $\begin{array}{r}\text { Per cent. } \\
1.7 \\
1.8 \\
1.8 \\
1.3 \\
1.5 \\
1.8 \\
1.6 \\
1.0\end{array}$ & $\begin{array}{r}\text { Per cent. } \\
6.8 \\
6.4 \\
6.6 \\
6.0 \\
7.3 \\
8.2 \\
6.7 \\
6.5\end{array}$ & $\begin{array}{r}\text { Per cent. } \\
3.46 \\
3.86 \\
3.77 \\
3.34 \\
3.26 \\
3.77 \\
3.57 \\
2.85\end{array}$ & $\begin{array}{r}\text { Pounds. } \\
4.95 \\
5.60 \\
5.75 \\
7.12 \\
6.56 \\
5.83 \\
4.72 \\
7.18\end{array}$ \\
\hline $\begin{array}{l}\text { Herd No. 2, Lajas: } \\
\text { November, } 1920 . . \\
\text { December, } 1920 . . \\
\text { January, } 1921 \ldots . . \\
\text { February, } 1921 \ldots \\
\text { March, } 1921 \ldots \ldots \\
\text { April, } 1921 \ldots \ldots . \\
\text { May, } 1921 \ldots \ldots . \\
\text { June, } 1921 . \ldots \ldots . \\
\end{array}$ & \begin{tabular}{r|}
104 \\
105 \\
103 \\
109 \\
100 \\
95 \\
104 \\
114
\end{tabular} & \begin{tabular}{l|}
515.9 \\
591.5 \\
52.8 \\
648.4 \\
653.6 \\
50.4 \\
443.8 \\
787.7
\end{tabular} & $\begin{array}{l}15,478.5 \\
18,429.5 \\
16,391.4 \\
18,155.0 \\
20,431.1 \\
15,162.0 \\
13,757.8 \\
23,631.0\end{array}$ & $\begin{array}{l}724.71 \\
858.80 \\
786.05 \\
738.91 \\
910.87 \\
719.88 \\
780.70 \\
893.97\end{array}$ & $\begin{array}{l}1.0 \\
2.0 \\
2.0 \\
1.4 \\
1.6 \\
2.4 \\
3.0 \\
1.5\end{array}$ & $\begin{array}{r}8.8 \\
11.0 \\
9.0 \\
8.5 \\
7.4 \\
9.4 \\
11.0 \\
7.7\end{array}$ & $\begin{array}{r}4.68 \\
.4 .66 \\
4.79 \\
4.07 \\
4.45 \\
4.75 \\
5.67 \\
3.78\end{array}$ & $\begin{array}{l}4.96 \\
5.66 \\
5.09 \\
5.95 \\
6.54 \\
5.32 \\
4.27 \\
6.90\end{array}$ \\
\hline 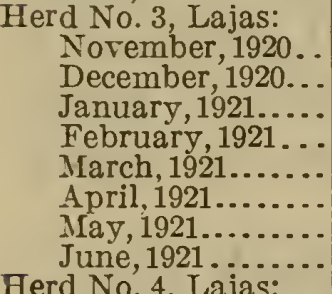 & $\begin{array}{l}50 \\
54 \\
46 \\
43 \\
41 \\
55 \\
56 \\
65\end{array}$ & $\begin{array}{l}373.0 \\
341.6 \\
326.3 \\
254.8 \\
289.6 \\
-462.9 \\
401.0 \\
639.8\end{array}$ & $\begin{array}{r}11,190.0 \\
10,589.6 \\
10,086.3 \\
7,142.8 \\
8,977.8 \\
13,887.0 \\
12,231.0 \\
19,194.0\end{array}$ & $\begin{array}{l}489.60 \\
516.90 \\
441.36 \\
310.62 \\
370.01 \\
555.87 \\
461.11 \\
637.88\end{array}$ & $\begin{array}{l}2.0 \\
2.6 \\
2.8 \\
2.2 \\
2.2 \\
1.8 \\
2.4 \\
1.7\end{array}$ & $\begin{array}{l}7.6 \\
7.6 \\
7.2 \\
7.5 \\
7.6 \\
8.5 \\
6.6 \\
6.2\end{array}$ & $\begin{array}{l}4.38 \\
4.88 \\
4.37 \\
4.35 \\
4.12 \\
4.03 \\
3.74 \\
3.81\end{array}$ & $\begin{array}{l}7.46 \\
6.32 \\
7.09 \\
5.92 \\
7.06 \\
8.41 \\
7.16 \\
9.84\end{array}$ \\
\hline 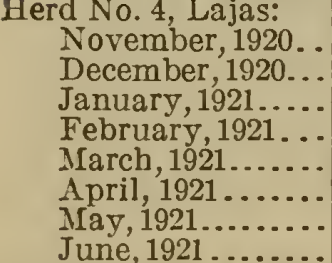 & $\begin{array}{l}104 \\
109 \\
106 \\
114 \\
111 \\
122 \\
112 \\
126\end{array}$ & $\begin{array}{l}836.3 \\
978.2 \\
555.0 \\
471.0 \\
612.3 \\
775.0 \\
504.3 \\
770.1\end{array}$ & $\begin{array}{l}25,089.0 \\
30,324.9 \\
17,206.6 \\
13,294.6 \\
18,980.6 \\
19,854.0 \\
15,633.0 \\
23,103.0\end{array}$ & $\begin{array}{r}1,145.58 \\
1,303.83 \\
837.49 \\
589.30 \\
917.54 \\
935.18 \\
689.60 \\
926.44\end{array}$ & $\begin{array}{l}2.2 \\
2.0 \\
2.4 \\
1.1 \\
3.0 \\
2.4 \\
1.8 \\
1.8\end{array}$ & $\begin{array}{r}8.4 \\
6.6 \\
9.2 \\
8.2 \\
8.8 \\
7.0 \\
6.7 \\
10.0\end{array}$ & $\begin{array}{l}\text { 4. } 57 \\
\text { 4. } 30 \\
\text { 4. } 86 \\
\text { 4. } 36 \\
\text { 4. } 83 \\
\text { 4. } 71 \\
\text { 4. } 41 \\
\text { 4. } 01\end{array}$ & $\begin{array}{l}8.04 \\
8.97 \\
5.24 \\
4.13 \\
5.51 \\
6.35 \\
4.50 \\
6.11\end{array}$ \\
\hline $\begin{array}{l}\text { Herd No. } 5 \text {, Maya- } \\
\text { guez: }\end{array}$ & & & & & & & & \\
\hline 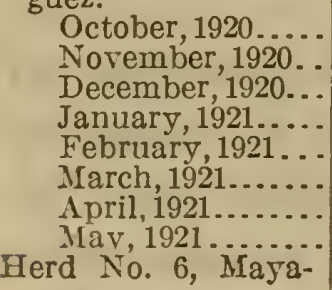 & $\begin{array}{l}17 \\
23 \\
19 \\
18 \\
18 \\
17 \\
20 \\
21\end{array}$ & $\begin{array}{l}178.6 \\
208.3 \\
173.2 \\
189.6 \\
177.2 \\
220.5 \\
226.5 \\
255.1\end{array}$ & $\begin{array}{l}5,536.6 \\
6,249.0 \\
5,369.2 \\
5,877.6 \\
4,961.6 \\
6,823.1 \\
6,795.0 \\
7,908.1\end{array}$ & $\begin{array}{l}281.26 \\
285.03 \\
276.52 \\
285.96 \\
234.76 \\
306.59 \\
312.76 \\
353.17\end{array}$ & $\begin{array}{l}4.0 \\
3.0 \\
4.2 \\
3.8 \\
3.9 \\
3.5 \\
3.0 \\
3.3\end{array}$ & $\begin{array}{l}6.7 \\
8.0 \\
8.5 \\
7.7 \\
7.2 \\
5.8 \\
6.5 \\
6.4\end{array}$ & $\begin{array}{l}5.08 \\
4.56 \\
5.15 \\
4.87 \\
4.62 \\
4.49 \\
4.60 \\
4.47\end{array}$ & $\begin{array}{r}10.50 \\
9.06 \\
9.11 \\
10.53 \\
9.81 \\
12.97 \\
11.32 \\
12.15\end{array}$ \\
\hline 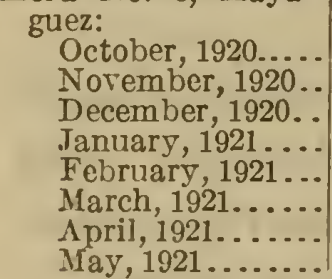 & $\begin{array}{l}7 \\
7 \\
7 \\
7 \\
6 \\
4 \\
6 \\
6\end{array}$ & \begin{tabular}{l|}
69.4 \\
66.0 \\
59.4 \\
55.8 \\
46.9 \\
44.1 \\
74.0 \\
67.2
\end{tabular} & $\begin{array}{l}2,151.4 \\
1,980.0 \\
1,811.4 \\
1,729.8 \\
1,312.8 \\
1,367.1 \\
2,220.0 \\
2,083.2\end{array}$ & $\begin{array}{c}112.84 \\
108.45 \\
103.11 \\
93.95 \\
69.58 \\
71.52 \\
97.49 \\
92.67\end{array}$ & $\begin{array}{l}4.8 \\
4.9 \\
5.0 \\
4.8 \\
4.5 \\
4.4 \\
3.7 \\
3.6\end{array}$ & $\begin{array}{l}6.0 \\
5.9 \\
6.3 \\
7.4 \\
6.2 \\
6.0 \\
5.7 \\
6.2\end{array}$ & $\begin{array}{l}5.24 \\
4.90 \\
5.60 \\
5.43 \\
5.3 \\
5.5 \\
4.39 \\
4.45\end{array}$ & $\begin{array}{r}9.91 \\
9.43 \\
8.48 \\
7.97 \\
7.81 \\
11.02 \\
12.33 \\
11.20\end{array}$ \\
\hline
\end{tabular}

${ }^{1}$ Burcau of Animal Industry Circ. 179, Cow Testing Associations. 
General results of comparative tests made to determine the dairy yield of cous in Porto Rico-Continued.

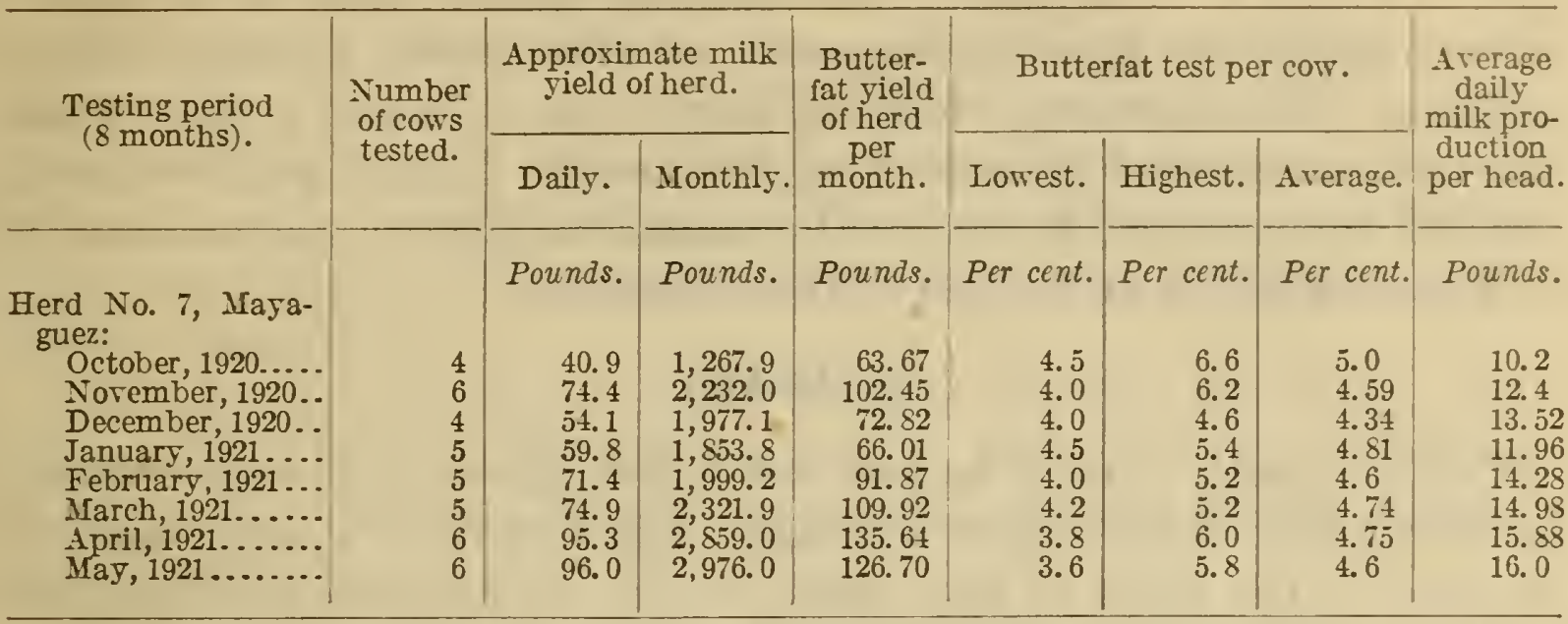

The results given in the foregoing table were obtained by weighing the milk, drawing samples, and making Babcock tests of the milk. As the seasons vary but little in Porto Rico and the cattle are allowed to graze the year round, the results are more uniform for the months during which the study was made than they would be in temperate regions. Only those cows which were being milked at the respective dairies were tested. Some of them were coming in fresh and others were going dry through the period of the test. The results from individual cases are rather indefinite, but the average for the whole herd is very good. Herd No. 1 was pastured on Guinea grass at Guanica, a dry section of the island on the south coast. The animals were milked once a day, with the calf. Herds Nos. 2, 3, and 4 had Guinea grass as the principal feed and were kept at Lajas, a dry section in the southwestern part of the island. This section, which has a limestone soil, is considered ideal for cattle raising. The cows in these herds were milked once a day, with the calf. Herd No. 5 carries more or less improved blood, having been bred to the station bulls. This herd was kept near Mayaguez, not far from the experiment station, in the western part of the island. The cows were milked twice a day, some with and some without the calf. Herd No. 6 belongs to the College of Agriculture of the University of Porto Rico, Mayaguez, and consists of purebred animals. The cows in this herd were milked twice a day without the calf. Herd No. 7 is made of high-grade animals, mostly of Guernsey blood, and belongs to the station. (Pl. II, Fig. 2.) The cows were milked twice a day, without the calf.

The general results indicate the need of introduced blood to improve the milk stock of the island, and more modern methods of milking and handling than are now used. It is a noticeable fact that the native cows varied greatly in yields of milk and butterfat. The high-testing cows gave such large yields as to indicate that they are 
a good foundation stock that is acclimated and immune to tick fever. (Pl. I, Fig. 2.) The small yields and low tests of some of the other cows conclusirely show the necessity of eliminating all unprofitable animals. The increased yields of herds Nos. 5,6 , and 7 show what can be accomplished by improving the breed. A good purebred sire, the best that can be afforded, will do much to improve the uniformity and quality of the milk yield of the progeny.

\section{SUMMARY.}

Cattle should have a larger and better place in the agriculture of Porto Rico than is now the case. They provide a large amount of food in the form of beef, milk, cream, and cheese, and the cost of their upkeep is relatively small. Every farm, no matter how small, should keep at least one cow. Even one cow will utilize what are now waste products of the farm, gire milk for the family, and add to the family income by her yield of marketable dairy products. Cattle help to conserve the fertility of the soil by returning to it in the form of manure a large percentage of the fertilizing constituents in the feed. The fertility thus utilized considerably lessens the cost and upkeep of the animals.

Porto Rico should produce a large number of fine dairy cattle, since it is possible to produce large yields of elephant grass, velvet beans, and other forage crops that are greatly relished by such cattle. There is still room for improvement in forage production, however, and grasses that are rich in quality as well as abundant in quantity should be more extensively grown. Improved grasses should be planted on all the idle lands of the island. 'The increased yields will help to build up the animal industry of the country because more cattle will likely be raised by the owners of lands growing the nutritious grasses. When one farmer puts his idle land to work and gets good results in the form of good yielding crops and cattle, other farmers will be influenced to do the same and the community will be thus benefited.

Porto Rico has a good foundation in her native stock, but the cattle should be bred for some special purpose. Although the dairy cow now brings a greater return for the amount of money expended on her than any other farm animal, such cows should be bred with a view to increasing the quantity and quality of the milk yield. The native herd can be improved by the introduction of new blood. Good sires should be purchased for this purpose, but until the tick is eradicated cattle from the North should be handled with great care. because they are very susceptible to tick fever and soon succumb. When an importation is made, only purebred animals of the hicrhest type should be purchased. Until the tick has been 
eradicated the farmer can grade up his native herds by using a better sire than the one preceding it.

The animals should receive every possible attention throughout the whole of their lives, but especially during the natural growing period. They should be well fed, comfortably housed, and shielded from exposure to tick infestation, disease, and the elements, fatigue, overcrowding, and from anything that tends to frighten them or make them timid.

Only those cattle that transmit to their offspring the high-producing qualities of their ancestors should be kept, and the unprofitable cow, that is, the one which gives poor yields, should be eliminated from the herd.

The animals should be given plenty of fresh, clean water, it being remembered that they need between 50 and 100 pounds a day, depending upon the feed.

The stockman should remember that the secret of successful cattle raising is careful selection, constructive breeding, and skillful feeding with well-balancerl rations. 



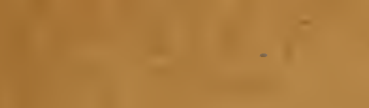

$=-1$

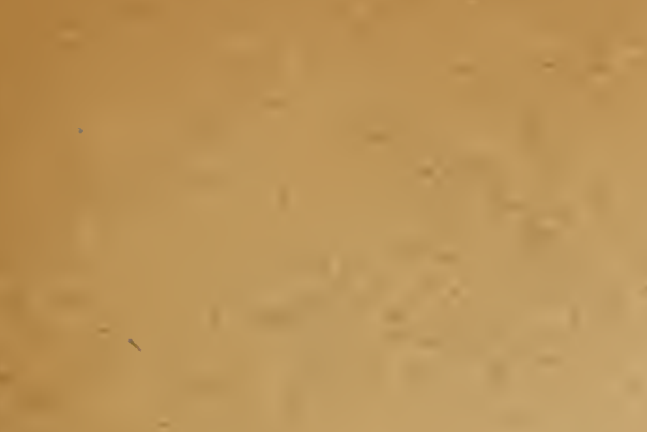

4

$2-5=-5=$

s. II :

s:

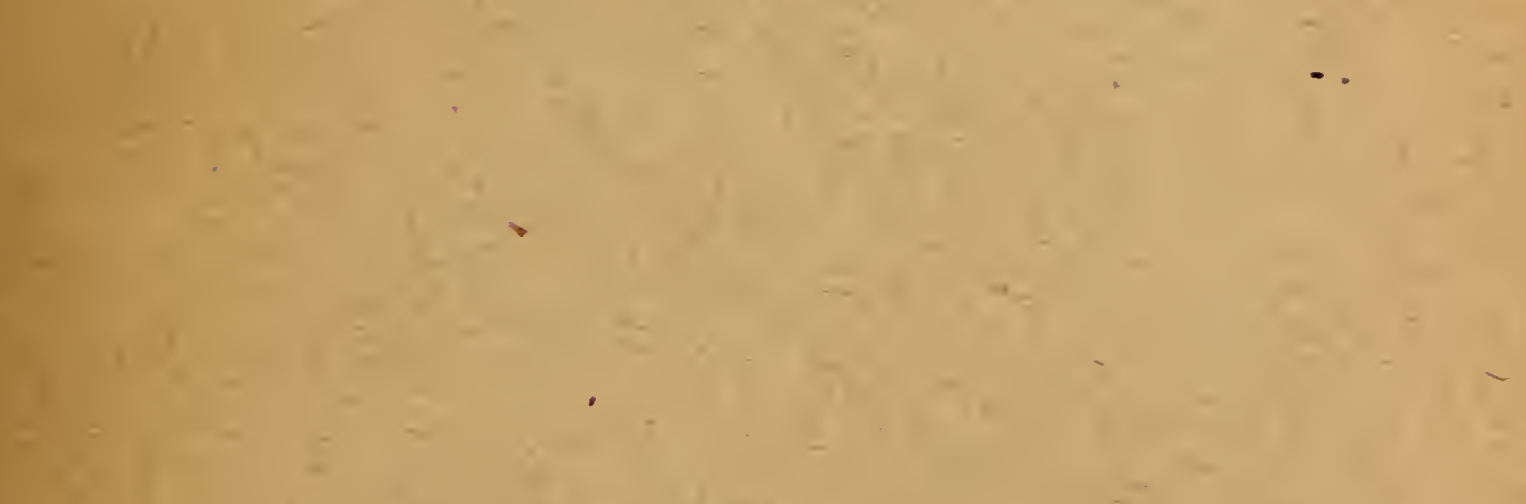

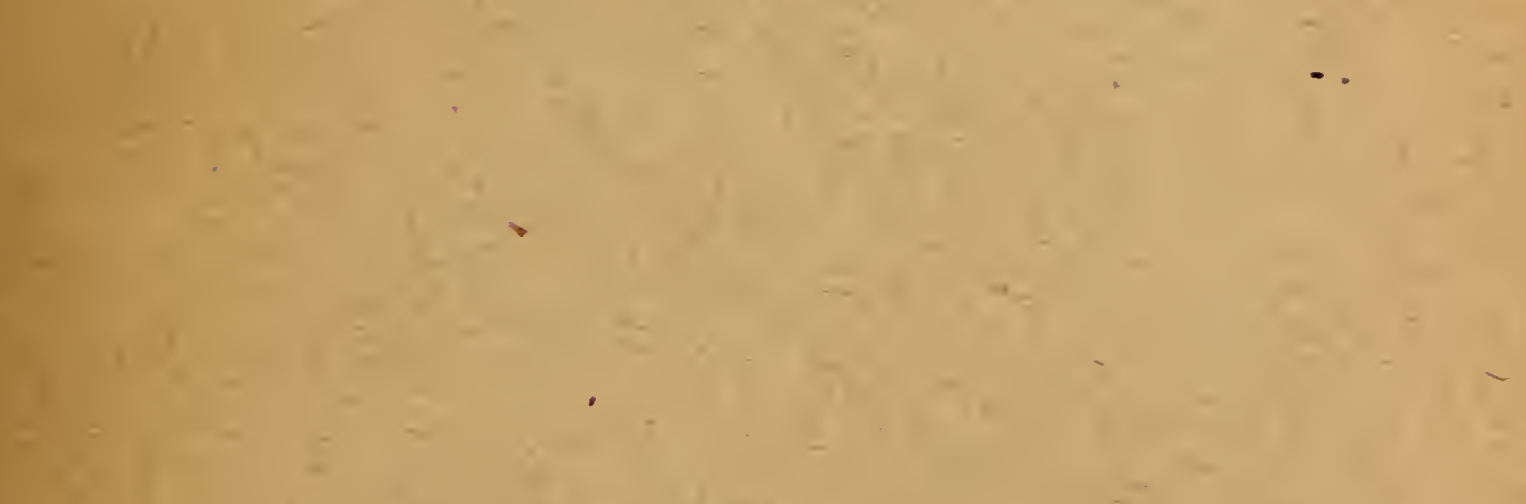

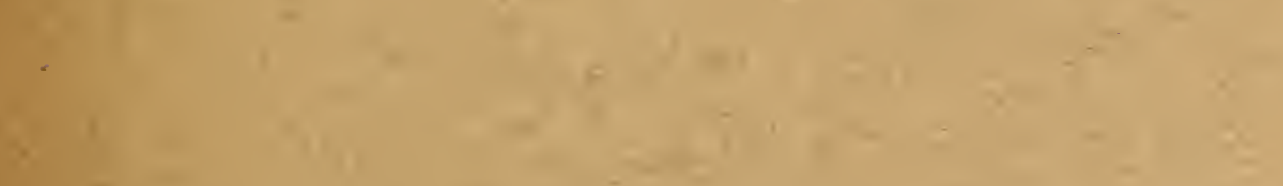

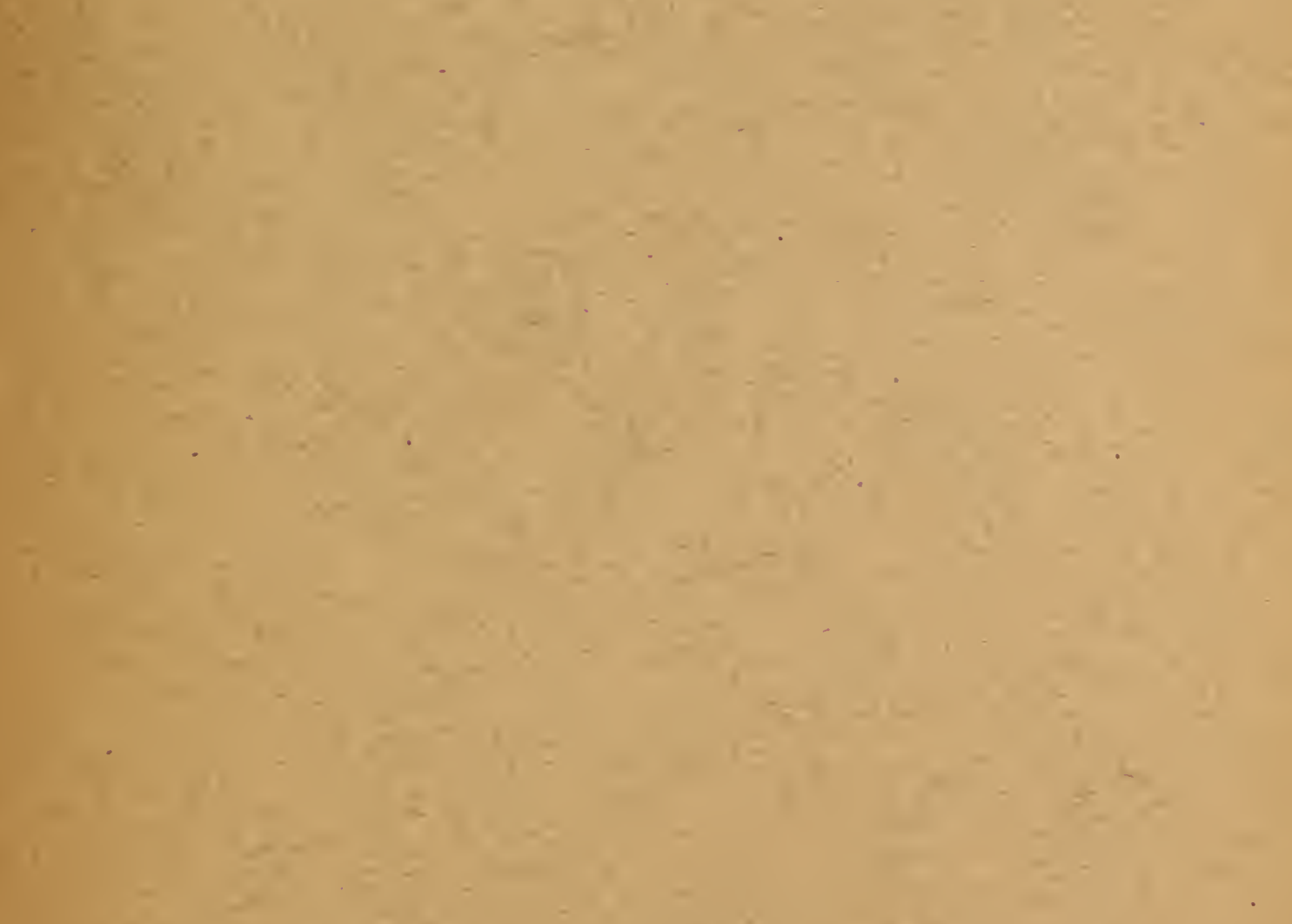

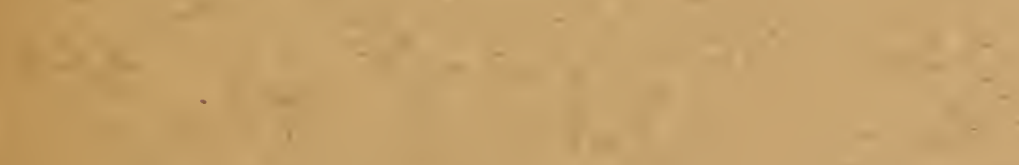

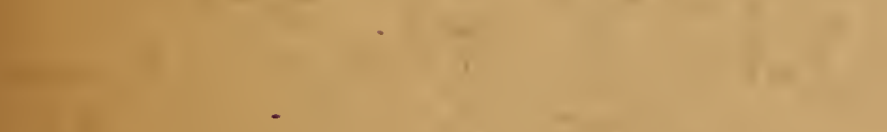

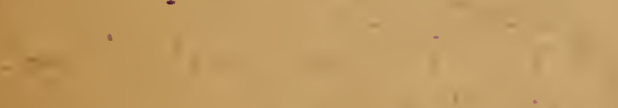

$+2+2+2=$

$\begin{array}{lll}3-x & +2 \\ 1 & 1 & 1\end{array}$

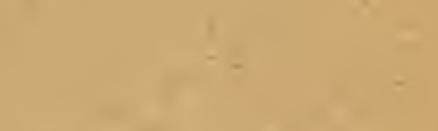


